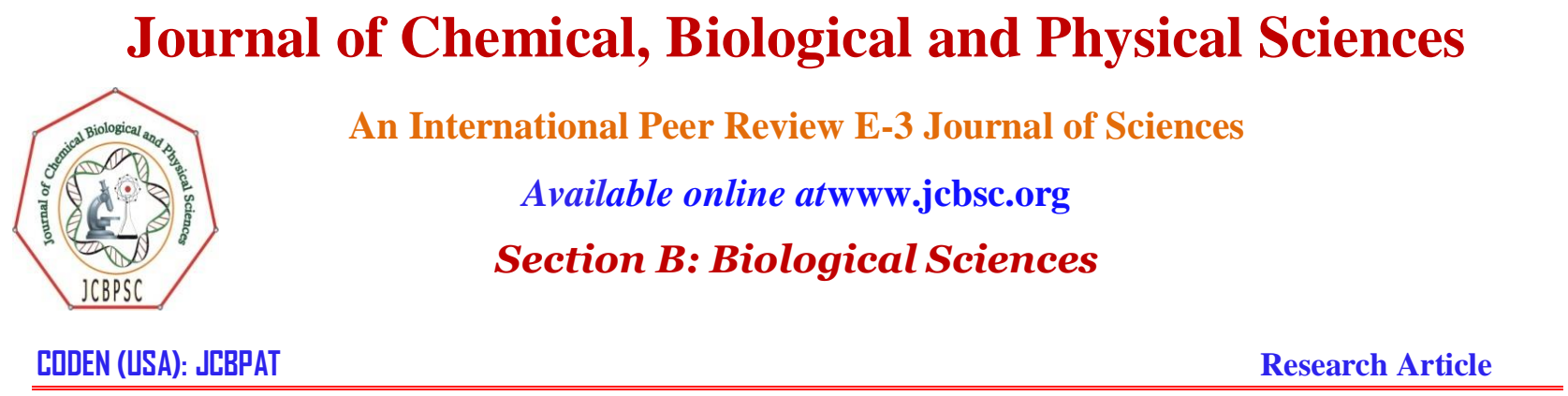

\title{
Role of Probiotic Health Drinks In Health Sector
}

\author{
Seema Ahuja *, Navneet kaur and Tarun Goyal \\ Department of Agriculture, Baba Farid College, Deon, Bathinda
}

Received: 30 October 2017; Revised: 10 November 2017; Accepted: 15 November 2017

\begin{abstract}
There is no doubt that probiotics generate one of the most promising and dynamically developing segments of food industry. There are several factors supporting the inflow of functional products like the increasing consumer awareness in combination with new advances in various scientific domains. Functional foods have been developed virtually in all food categories, however their distribution over the segments of the market is not homogeneous and product preferences may vary between markets. The development and commerce of probiotic products is rather complex, expensive and risky, as special requirements should be answered. In the case of a successful product development attention should be paid both to consumer demands and technical conditions, furthermore, the legislation background should also not be neglected. Multinational companies possess the adequate $R \& D$ activities, they know the economic potential due to their well-known products that give them the opportunity to introduce a brand new product to the market. Consumer acceptance, however, is determined by a number of factors such as primary health concerns, consumers' familiarity with the "probiotics" concepts and with the functional ingredients, the nature of the carrier product, the manner of health effect communication, etc. The message of the health effect of a specific product should be transferred via credible media in a relatively simple way, so that it could be easily achieved by the consumers. As a rule, consumers seem to evaluate functional foods first and foremost as foods. Functional benefits may provide added value to consumers but cannot outweigh the sensory properties of foods. These products provide consumers a modern way to follow a healthy lifestyle, which differs from the conventionally healthy diet defined by nutrition experts. In general, the attitude
\end{abstract}


both to functional foods and to their consumers is positive, so such a concept represents a sustainable trend in a multi-niche market.

Keywords: Globalization, yoghurt drink, probiotics

\section{INTRODUTION}

The biggest problems today is the increase in the obesity rates suffered in most countries. Globalization has caused a change in the eating habits of the urban, rural and semi rural populations. The increased consumption of junk food, the lack of exercise, the sedentary and accelerated lifestyle have not allowed the population to consume healthy and nutritious foods that favor their health. This problem is so serious that could cause the collapse of health systems. Among the new and innovative foods that have arisen, and that also represent a healthy eating option for people, there are probiotic drinks ${ }^{1}$. Probiotic food products have been consumed by human beings in the form of fermented foods, for many years According to the report by FAO/WHO, probiotics are: "Live microorganisms which, when administered in adequate amounts, confer a health benefit to the host".

The most common types of probiotics are Lactic acid bacteria and include species from the Lactobacillus, Pediococcus and Bifidobacterium genera. An important characteristic of probiotic bacteria is that they need to survive through the gastro intestinal tract of the host e.g. survival of bifidobacteria spp. could lead to new products for the dairy market ${ }^{2}$. Probiotics, especially Lactobacillus and Bifidobacterium have been suggested to be associated with alleviation of lactose intolerance ,prevention and cure of viral, bacterial and antibiotic or radiotherapy induced diarrheas, immunomodulation, antimutagenic and anticarcinogenic effects and even blood cholesterol reduction ${ }^{3}$.

The concept of probiotics was introduced in early 20th century by Elie Metchnikoff, it however gained momentum only recently with considerable and significant advances in functional and health food market across the world. India is also fast emerging as a potential market for probiotics in food. The global probiotic market generated US $\$ 15.9$ billion in 2008 and is expected to be worth US\$ 32.6 billion by 2014 with a compound annual growth rate of $12.6 \%$ from 2009 to 2014. On the other hand the probiotic product industry in India was estimated to be around Rs 20.6 million with a projected annual growth rate ${ }^{3}$ of $22.6 \%$ until 2015.

\section{MARKETING COVERAGE WORLD-WIDE}

The consumer health market covers a wide range of products, all of which claim to improve some aspect of health or wellbeing and probiotics is one of them. Recently, both in Japan and Europe the market of probiotics is dominated by gut health products, in particular probiotics with 379 product launches worldwide $^{4}$ in 2005 . Lactic acid bacteria (LAB) and bifidobacteria, the most studied and widely employed bacteria within the probiotic field, are normal components of the intestinal microbiota and have a long tradition of safe application within the food industry ${ }^{5}$.Among probiotics dairy products are the key product sector accounted for sales of around 1.35 billion US\$ in 1999 and about $56 \%$ of probiotics total 31.1 billion US\$ global sales in. The main markets of dairy probiotics are Scandinavia, the Netherlands, Switzerland, Croatia, Estonia, while Greece, France and Spain can be considered as developing markets 
Germany, France, the United Kingdom and the Netherlands account for around two thirds of all sales of functional dairy products in Europe. Such products have shown an impressive growth during recent years, bringing the market volume in Germany from around 5 million US\$ in 1995 to 419 million US\$ in 2000, of which 301 million US\$ account for pro-, prebiotic and other functional yogurts and around 118 million US\$ for functional dairy drinks. In Central-Eastern Europe, e.g. in Czech Republic, Hungary or Romania the probiotics market is dominated by international companies such as Unilever or Danone and the majority of the national producers are only able to adopt technologies and product ingredients developed in other countries.

There is however an extensive research and development activity concerning probiotics resulted in a great number of special new dairy products. This success of dairy probiotics can partly be explained by their general positive image among consumer, however several other factors support the development: the products kept at cold, they have relatively short shelf life (28-35 days), all nutrients for probiotics growth available and guidelines as well as regulations for dairy applications are readily available. On the contrary the sensitivity of probiotics to physical and chemical stress, heat and acidity makes the product development challenging for other type of food products. Recently, encapsulation was assessed as possible technology for decreasing sensitivity of such probiotics. Fruit juice has also been suggested as a novel, appropriate medium for fortification with probiotic cultures because it is already positioned as a healthy food product, and it is consumed frequently and loyally by a large percentage of the consumer population. However, research has shown that, perceptible off-flavours are associated with probiotic orange juices which might be a limitation of the market success ${ }^{6}$.

\section{A TALE OF TWO BRANDS}

The story of small innovator Yakult and fast follower Danone reveals how large global consumer company can over -power a local specialist, even industry where proof of health claim is critical. In 1935, Yakult, a small japanese company, launched a probiotic yoghurt-like drink containing the Lactobacillus Casei bacteria. The company claimed the product helped improve stomach health by promoting good bacteria and had the evidence to prove it. It was generally disturbed through health food shop and pharmacies. In 1994, global giant Danone known as Dannon in the united states, saw the market potential and laucnched Actimel, yoghurt drink sold as Dan Active in the United States and Canada. It features Lactobacillus Casei bacteria which the company claimed had stomach smoothing effects similar to the bacteria in Yakults drink. Danone's product was supported by a huge marketing campaign in major supermarkets and within a couple of years Actimel was the market leader.

However, the aggressive marketing approach adopted by Danone resulted in it being caught by the increasing regulation of health claims. Activia had been marketed as easing the digestive system and actimel claimed to reinforce the body's protection against disease. In 2010 Danone was summoned by the European commission for false product claims stating that the evidence didn't support its advertising claims. Despite the necessary change in the claims being made,Actimel remains the market leader. In the final twist into the tail, 2000, Danone took a 3\% stay in the company that manufacturers Yakult is currently looking to increase that stake above its current 20\%. Yakult's president opposes the increase, saying it could impact the company's independence. 
Table 1: Some commercial examples of probiotic products available globally:

\begin{tabular}{|c|c|c|}
\hline Brand/Trade Name & Description & Producer \\
\hline Actimel & $\begin{array}{l}\text { Probiotic drinking yogurt with L. casei Imunitass1 } \\
\text { cultures,Danone }\end{array}$ & France \\
\hline Activia & $\begin{array}{l}\text { Creamy yogurt containing Bifidus } \\
\text { ActiRegularis1,Danone }\end{array}$ & France \\
\hline Gefilus & A wide range of LGG products Valio, & Finnland \\
\hline Hellus & $\begin{array}{l}\text { Dairy products containing Lactobacillus fermentum } \\
\text { ME-3 Tallinna Piimato“o” stuse AS, }\end{array}$ & Estonia \\
\hline Jovita & $\begin{array}{l}\text { Probiotisch Blend of cereals, fruit and probiotic } \\
\text { yogurt H\&J Bruggen, }\end{array}$ & Germany \\
\hline Pohadka & $\begin{array}{l}\text { Yogurt milk with probiotic cultures Valas`ske' } \\
\text { Mezir` }{ }^{\prime}{ }^{\prime} \mathrm{c}^{`}{ }^{\prime} \text { Dairy }\end{array}$ & Czech Republic \\
\hline ProViva & $\begin{array}{l}\text { Refreshing natural fruit drink and yogurt in many } \\
\text { different } \\
\text { flavours containing Lactobacillus plantarum } \\
\mathrm{Ska}^{\circ} \text { ne mejerier }\end{array}$ & Sweden \\
\hline Rela Yogurts & $\begin{array}{l}\text { cultured milks and juices with L. reuteri Ingman } \\
\text { Foods }\end{array}$ & Finland \\
\hline Revital Active & Yogurt and drink yogurt with probiotics Olma & Czech Republic \\
\hline Snack Fibra & $\begin{array}{l}\text { Snacks and bars with natural fibers and extra } \\
\text { minerals } \\
\text { and vitamins }\end{array}$ & Celigu“ eta, Spain \\
\hline SOYosa & $\begin{array}{l}\text { SOYosa Range of products based on soy and oats } \\
\text { and includes } \\
\text { a refreshing drink and a probiotic yogurt-like soy- } \\
\text { oat product } \\
\text { Bioferme }\end{array}$ & Finland \\
\hline Soytreat & Kefir type product with six probiotics Lifeway & USA \\
\hline Yakult & $\begin{array}{l}\text { Milk drink containing Lactobacillus casei Shirota } \\
\text { Yakult, }\end{array}$ & Japan \\
\hline Yosa & $\begin{array}{l}\text { Yogurt-like oat product flavoured with natural fruits } \\
\text { and berries containing probiotic bacteria } \\
\text { (Lactobacillus } \\
\text { acidophilus, Bifidobacterium lactis) } \\
\text { Bioferme, }\end{array}$ & Finland \\
\hline Vitality & $\begin{array}{l}\text { Yogurt with pre- and probiotics and omega- } 3 \mathrm{Mu} * \\
\text { ller }\end{array}$ & Germany \\
\hline Vifit & $\begin{array}{l}\text { Drink yogurts with LGG, vitamins and minerals } \\
\text { Campina }\end{array}$ & the Netherlands \\
\hline
\end{tabular}

Danisco is targeting the North American market for children's milk drinks with the launch of its probiotic blend Howaru. Clinically proven to reduce cold and flu symptoms, the launch is a response to parental focus on child health during the winter season. Creating new concepts for young tastes can inspire manufacturers in their product development. Danisco has already produced a series of drinks for

81 J. Chem. Bio. Phy. Sci. Sec. B, November 2017 - January 2018, Vol. 8, No.1, 078-083. [DOI:10.24214/jcbps.B.8.1.07883.] 
children containing three of the most documented commercial probiotic strains, recognised for their immune-modulating properties. Yoplait Kids contains Martek's DHA Omega-3 for brain, eye and heart health.

\section{CONCLUSION}

There is no doubt that probiotics generate one of the most promising and dynamically developing segments of food industry. There are several factors supporting the inflow of functional products like the increasing consumer awareness in combination with new advances in various scientific domains. Functional foods have been developed virtually in all food categories, however their distribution over the segments of the market is not homogeneous and product preferences may vary between markets. The development and commerce of probiotic products is rather complex, expensive and risky, as special requirements should be answered. In the case of a successful product development attention should be paid both to consumer demands and technical conditions, furthermore, the legislation background should not be neglected. Multi-national companies possess the adequate R\&D activities, the know the economic potential due to their well-known products, that give them the opportunity to introduce a brand new product to the market. Consumer acceptance, however, is determined by a number of factors such as primary health concerns, consumers' familiarity with the "probiotics" concepts and with the functional ingredients, the nature of the carrier product, the manner of health effect communication, etc. Consumers' knowledge and awareness of the health effects of newly developed functional ingredients seems to be rather limited, therefore there is strong need for specific communication activities to consumers in this respect. The message of the health effect of a specific product should be transferred via credible media in a relatively simple way, so that it could easily achieved by the consumers. As a rule, consumers seem to evaluate functional foods first and foremost as foods. Functional benefits may provide added value to consumers but cannot outweigh the sensory properties of foods.. These products provide consumers a modern way to follow a healthy lifestyle, which differs from the conventionally healthy diet defined by nutrition experts. In general, the attitude both to functional foods and to their consumers is positive, so such a concept represents a sustainable trend in a multi-niche market.

\section{REFRENCES}

1. A.L.Y. Moneda, L.M.R. Murillo, Analysis of factors that affect the marketing of a new probiotic drink made from maguey juice in an urban community in the state of pubela, Mexico, Proceedings of $8^{\text {th }}$ annual London business research conference imperial college, London, 2013.

2. U.Teotia, R.Kumar, A.K. Mishra Deepa, V. Malik, A role of beverages in human health with special references of probiotic milk. Journal of Asian Pac. Health sciences, 2014, 1(3), 162-173.

3. N.K. Ganguly, ICMR_DBT Guidelines for evaluation of probiotics in food, 2011.

4. A.Ouwehand, Success in applying pro- and prebiotics in dairy products. In Proceedings of the fourth international meeting on functional foods, 2007.

5. G. Kociubinski, \& S.Salminen, Probiotics: Basis, state of the art and future perspectives. Functional food network general meeting, 2006, 
6. I. Siro, E. Kapolna, B. Kaplona, A. Lugasi, Functional Food a Product development, marketing and consumer acceptance-a review, Journal Appetite of Elsevier, 2008, 51, 456-467.

\section{Corresponding author: Seema Ahuja,}

Department of Agriculture, Baba Farid College, Deon, Bathinda.

Online publication Date: 15.11.2017 